\title{
Macroeconomic Aspects of Private Retirement Programs
}

\author{
Krzysztof M. Ostaszewski*
}

\begin{abstract}
The decline in importance of private defined benefit plans in relation to defined contribution plans in the United States is a major issue of interest to pension actuaries. This decline has been attributed to numerous factors: costs of government regulation, societal and cultural changes, changed employer attitudes, and employees' lack of understanding of defined benefit plans. It has also caused some observers to proclaim the end of private defined benefit plans. This paper analyzes possible macroeconomic factors contributing to the crisis of defined benefit plans and proposes an alternative hypothesis for the cause of the crisis: the decline of the relative attractiveness of defined benefit plans in relation to defined contribution plans when these are viewed as investments, that is, as securities in capital markets.
\end{abstract}

\section{Introduction: Are Defined Benefit Pension Plans an Endangered Species?}

For more than two decades, traditional defined benefit (DB) plans in the United States have been declining in relative importance. As indicated by the U.S. Department of Labor (2000), during the period 1977-96 the number of DB plans in the United States fell at an average annual rate of $3.19 \%$, while the number of defined contribution (DC) plans grew in the same period at an annual rate of $4.14 \%$. During the period 1975-96, total DB plan assets grew at a nominal annual rate of $10.23 \%$, while total DC plan assets grew at a nominal annual rate of $14.83 \%$. In 1975 total contributions to DB plans were $\$ 24.2$ billion, nearly twice the $\$ 12.8$ billion total contributions to DC plans in the same year. In 1996 total contributions to DB plans amounted to $\$ 35.8$ billion, nearly one-fourth of the $\$ 133.7$ billion total 1996 contributions to DC plans. Note that contributions to DB plans were in a steady decline in nominal dollars from 1984 through 1990, and increases in such contributions have occurred only in the period 1991-93, followed by a resumed decline.

\footnotetext{
* Krzysztof M. Ostaszewski, Ph.D., F.S.A., M.A.A.A., is Actuarial Program Director at Illinois State University, Normal, IL 61790-4520, e-mail: krzysio@ilstu.edu.
}

Finally, the total amount of benefits paid by DB plans in 1975 was more than double that for DC plans ( $\$ 12.9$ billion versus $\$ 6.2$ billion), but in 1996 benefits paid by DC plans (\$116.5 billion) exceeded those paid by DB plans (\$96.9 billion) for the second year in a row (the first time DC benefits paid ever exceeded DB benefits paid was in 1995). In 1996, total assets of DB plans still constituted the majority (50.6\%) of pension plan assets, but the trends indicated an imminent triumph of DC plans in terms of asset size. Of particular significance was the sizable increase in the assets of the $401(\mathrm{k})$ variety of DC plans (Poterba, Venti, and Wise 1994).

Figure 1, based on U.S. Department of Labor (2000) data, shows the relative share of pension plan assets held by DB plans, the portion of all new pension plan contributions that went into $\mathrm{DB}$ plans, the share of all pension benefits paid by DB plans, and the number of DB plan participants as a portion of the number of all pension plan participants. The figure clearly illustrates a strong shift toward DC plans in the last 22 years.

\section{Why Is This Happening?}

In a debate at a March 1988 meeting of the Canadian Institute of Actuaries moderated by Shiraz Bharmal (1988) the following resolution was proposed: "Defined benefit plans are not well suited 
Figure 1

Shares of Pensions in DB Plans

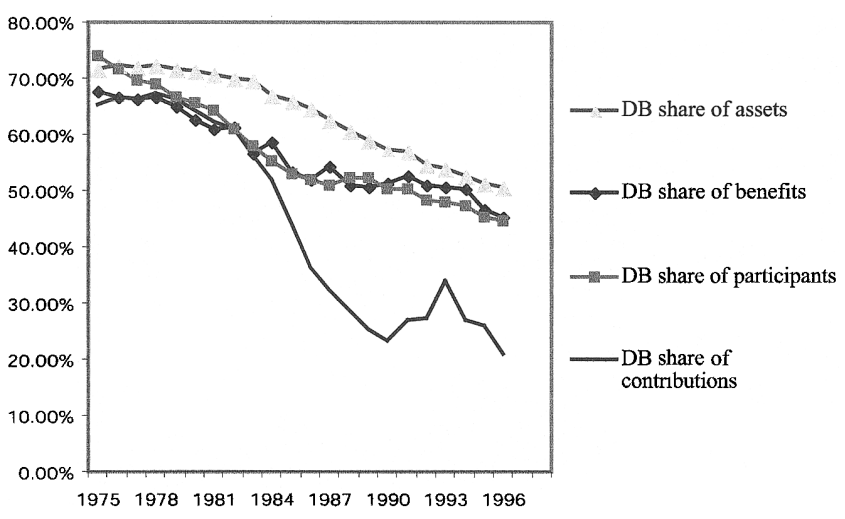

to tomorrow's work force and should be replaced by defined contributions plans." Two of the participants in the debate, Tom Holmes and Daniel McCaw, argued in favor of the resolution, presenting a list of factors causing the demise of DB plans. The list was indeed inclusive of what is commonly believed to be the causes of the shift to DC plans. One should note, however, that, in contrast with the United States, DB plans have not declined significantly in relation to DC plans in Canada.

The factors presented in the debate led by Bharmal (1988) are exactly the ones commonly brought forth to explain changes in pension structure in the United States and for that reason are presented here. (Let me stress that I do not endorse any of these theories at this point, but merely present them.)

\subsection{Change in the Relationship between Employer and Employees}

Today's workers are much less likely to retire from the same firm in which they began their careers, while firms are much less likely to view employees as lifetime workers. The result is that employees need direct ownership of their retirement accounts and full portability.

Furthermore, changes in culture, technology, and education have caused employees to be more self-directed and independent, making DC plans more desirable. This trend expresses itself both in the greater number of self-employed persons and in the severing of the bond between employers and employees; both groups are expressing more direct concern with their economic self-interest. DC plans offer an explicit and concrete measure of wealth, thus better matching the psychology of the new workplace environment. Also, DC plans tend to be more easily portable. This idea will be called the New Economy Theory.

\subsection{New Tax Laws and Funding Regulations Have Decreased the Attractiveness of DB Plans}

The passing of the Employee Retirement and Income Security Act (ERISA) of 1974 began the process of imposition of stricter legal, funding, and solvency requirements in the United States, including establishment of the Pension Benefit Guaranty Corporation (Marcus 1987). Similar requirements in Canada were put in place by the Pension Benefit Acts. Those stricter funding requirements also were accompanied by limiting access to surplus by employers. Accounting standards introduced by the Financial Accounting Statement Board in the United States and the Canadian Institute of Chartered Accountants in Canada reduced the flexibility of employers in accounting valuation of plans and brought upon them the necessity to perform both accounting and statutory valuations for DB plans, thus imposing additional costs.

The rules are made additionally complicated and costly by tax laws concerning deductibility of employer contributions to pension plans. Finally, both Canada and the United States impose limitations on the tax deductibility of contributions to other retirement accounts for workers participating in a DB plan, which may reduce perceived attractiveness of DB plans, even though the restrictions apply equally to DC plans. In addition, Daniel McCaw of William M. Mercer Inc. (Bharmal 1988) points out that in Canada legislators imposed mandatory inflation indexing on DB plans while making it voluntary for DC plans. McCaw concludes that, in his opinion, legislators in Canada are moving often unwilling employers toward DC plans.

The explanation of the historical shift from DB plans to DC plans as caused by government involvement appears to be the most popular among actuarial professionals. One of the main purposes of the present paper is to challenge this explanation (even though one must admit some of its 
merits). For the sake of simplicity, this set of ideas will be called the Excessive Regulation Theory.

\subsection{Distribution of Risk Between Employer and Employee}

The last 20 years have been marked by unprecedented volatility in financial markets. This has caused the cost of funding retirement benefits to be less predictable. One could argue that, under such circumstances, employees should value protection from uncertainty and seek refuge in DB plans. Indeed, such an argument is put forth in the Canadian Institute of Actuaries' debate moderated by Bharmal (1988) by Patrick Longhurst of Watson Wyatt Worldwide, who stressed that DC plan participants face the following flaws in their plans:

- Extreme volatility of benefit levels depending on investment performance.

- Significant impact of the choice of investment strategy.

- Inflexibility for employees hired in midcareer, who cannot be offered pension benefits beyond contribution limits.

- Difficulty in dealing with early retirement if sufficient assets have not been accumulated.

If, however, employers are fully aware of the risk distribution between DB and DC plans (while employees are less than fully informed), have become more risk-averse, and have full control of the type of the pension plan adopted, then a shift to DC plans would be expected. This will be called the Risk-Averse Employers Theory.

As defined by Longhurst (Bharmal 1988), the unit benefit equals the pension as a percentage of salary at retirement, divided by the years of service, assuming a portfolio invested $50 \%$ in bonds and $50 \%$ in equities. The unit benefit is a measure of how much of a pension an employee can earn for each year of service by investing in the benchmark portfolio. Some historical values of this index for selected years are shown in Table 1 . The table shows that funding of retirement has become cheaper in this period (i.e., the values in the table are, generally speaking, trending upward) but also somewhat unpredictable. Given that there was a massive movement to DC plans during the period, it can be argued that either em-
Table 1

Pension Unit Benefit

\begin{tabular}{|c|c|}
\hline Year & Unit Benefit \\
\hline 1977 & 0.0111 \\
1979 & 0.0122 \\
1981 & 0.0183 \\
1983 & 0.0139 \\
1985 & 0.0144 \\
1987 & 0.0173 \\
\hline
\end{tabular}

ployers were uncomfortable with increased investment risk and preferred to shift it to employees, or that employees wanted to benefit from high returns available in capital markets.

This paper will return to the question of employees' preferences, but note that the data raises some doubt about the idea that employers have been abandoning DB plans because of high expenses. Higher regulatory and legal expenses did indeed happen, but they coincided with higher returns available in the markets. In other words, pensions may have become more expensive because of having to pay actuaries and lawyers more, but they also have become cheaper because of higher returns. This makes the Excessive Regulation Theory somewhat less credible.

What is suspiciously missing from all of the above theories of the relative decline of DB plan importance is any economic motivation on the part of employees. Arguably, the New Economy Theory refers to the greater economic independence of individual workers (independence that may be wanted or unwanted, depending on the perspective), but it contains no reference to the rational self-interest of workers as economic decision makers. This absence in the actuarial literature is quite perplexing, and this paper will endeavor to address it.

\section{Economic Perspective on Pensions}

From the perspective of financial economics, participation in a pension plan is just another capital asset, a security similar to a Treasury bill, a share of stock, or a convertible bond. As in the case of any other security, plan participants give up today's cash flows (i.e., today's consumption) in return for future cash flows (i.e., future consumption). The major difference between DB pension 
plan participation and other securities is that the derivation of future cash flows of a DB plan participation is based on wages, not open market capital asset prices. A DB plan participant's forecasted value of plan participation is a function of length of service, salary, and other factors, such as vesting provisions, but the driving factor is the level of wages. In contrast, given the contribution level, the value of a DC plan participation is entirely a function of the performance of assets held by the participant.

Modern finance, as represented by the Capital Asset Pricing Model and Arbitrage Pricing Theory (Bodie, Kane, and Marcus 1999), argues that returns to financial assets are driven by their systematic risks, that is, nondiversifiable, societal risks assumed by having a position in a given capital asset. Participation in a DB plan, from the perspective of the plan participant, is a security that is purchased with wage concessions during the working career and whose payoff is the stream of pension benefits. It could be argued that the risks of capital markets are not present in that security. Indeed, this security can be considered free from asset default and equity market decline, as well as interest rate risk.

But it is not free of the risk of fluctuations of one macroeconomic factor, nondiversifiable to plan participants: the overall growth rate of wages in the national economy. It should be stressed that the rate of return to plan participants should not be confused with the internal rate of return on plan contributions. The plan sponsor assumes a long position in capital assets of the plan and pays for them with plan contributions.

Plan participants pay for their pension benefits with wage concessions throughout their careers, and their long, invested position is not in the plan assets, but in a security whose only uncertainty is tied to change in the overall level of wages in the national economy throughout their working career. Workers receive individual wage increases because of their individual merit and career progress, but these are not systematic, and not fully certain, and from the perspective of modern finance cannot be priced into the expected returns to plan participants. Only the macroeconomic factor of national wage growth is a source of systematic risk in DB pension plans, and as such it should determine the rates of return to plan participants. In this paper private DB plans are studied from that perspective.

Gwartney and Stroup (1995) provide data about average productivity and real wage increases in the United States in a subset of the post-World War II period (see Table 2). A general downward trend is seen in those quantities. Recall that the classical economic model of labor and capital as factors of production takes the production function as

$$
Y=F(K, L, t),
$$

where $Y$ is the production, $K$ is capital input, $L$ is labor input, and $t$ is time. The function $F$ is typically assumed to be homogeneous of degree one. It is also assumed that partial derivatives $\partial F / \partial K$ and $\partial F / \partial L$ are positive, while the second partials $\partial^{2} F / \partial K^{2}$ and $\partial^{2} F / \partial L^{2}$ are negative (the law of diminishing returns). Surrey (1976) provides a classical account of the problem of the distribution of the national income between capital and labor. Note that $\partial F / \partial K$ is called the marginal productivity of capital, and $Y / K$ is the average productivity (or average product) of capital; similarly $\partial F / \partial L$ is the marginal productivity of labor, and $Y / L$ is the average productivity (or average product) of labor.

The expressions

$$
\frac{\partial F / \partial K}{Y / K} \text { and } \frac{\partial F / \partial L}{Y / L}
$$

are called relative shares of capital and labor, respectively, and represent portions of new output that are due to the productivity increase of capital and labor, respectively. The most standard model of the production function is the CobbDouglas formula,

Table 2

\section{Productivity and Wage Growth in the United States}

\begin{tabular}{|c|c|c|}
\hline Period & $\begin{array}{c}\text { Average Annual } \\
\text { Productivity } \\
\text { Growth }\end{array}$ & $\begin{array}{c}\text { Average Annual } \\
\text { Real Wage } \\
\text { Growth }\end{array}$ \\
\hline $1948-55$ & $3.70 \%$ & $3.40 \%$ \\
$1956-68$ & 3.00 & 3.10 \\
$1969-80$ & 1.20 & 1.00 \\
$1981-92$ & 1.30 & 0.60 \\
\hline
\end{tabular}

Source: Gwartney and Stroup (1995). 
Figure 2

U.S. Real Weekly Wages (January)

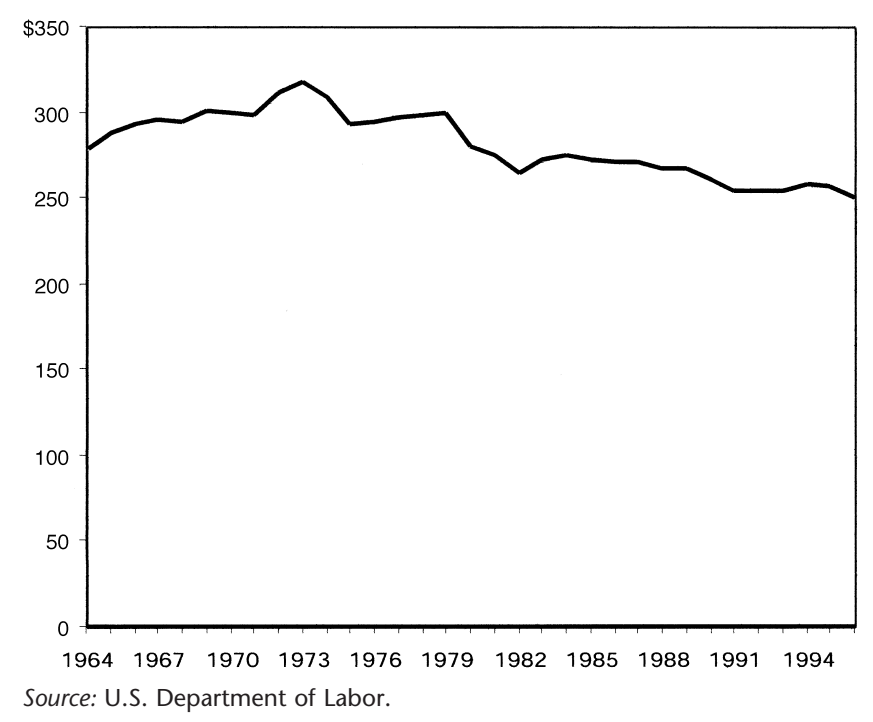

$$
Y=A K^{\alpha} L^{1-\alpha},
$$

where $A$ and $\alpha$ are constant parameters. In this case, we have

$$
\frac{\partial F / \partial K}{Y / K}=\alpha \text { and } \frac{\partial F / \partial L}{Y / L}=1-\alpha .
$$

If a given level of output is sought for the minimum total cost of capital and labor, the wellknown equilibrium condition is

Marǵinal Productivity of Labor

$$
\begin{aligned}
& \text { Price of Labor } \\
& =\frac{\text { Marǵinal Productivity of Capital }}{\text { Price of Capital }} .
\end{aligned}
$$

In a perfectly competitive labor market, the price of labor is equal to the marginal productivity of labor (Gwartney and Stroup 1995). It can be found from historical data that these two quantities do follow each other reasonably closely. (For fascinating evidence of how closely this theoretical result follows the historical reality of wages in the United States, see Cooper and Borden 1997.) Also observe that productivity increases have slowed since the 1970 s, resulting in a smaller rate of increase (or even in decreases) of real wages. Under the Cobb-Douglas function model of production, relative shares of labor and capital remain constant over time. The debate about whether these do indeed remain constant is one of the central issues in classical economics. The last two decades in the United States have brought lower rates of increase in real wages, while the real rates of return on capital have increased. The shares of the two factors of production may appear to have changed their relationship.

Figure 2 shows average real weekly wages (1996 dollars) in the United States in January of each year between 1964 and 1996, based on data provided by the U.S. Department of Labor. The data show a slightly declining trend, definitely not corresponding to the overall growth of the gross domestic product and the national economy in that period.

Figure 3 addresses another important issue. It shows the U.S. wages and salaries index, as provided by the Department of Labor, seasonally adjusted and in nominal values compared with nominal values of an amount equal to the initial value of the index invested in U.S. Treasury bills. The rate of return on Treasury bills has significantly exceeded the rate of growth of wages.

This means that over the 16 years presented in the graph investing in the wages and salaries index would have resulted, on a national average, in about half of the amount accumulated when compared to investing in Treasury bills. It is often argued that DC plan participants take too little risk with their assets, often placing them in money market instruments or Treasury bill

Figure 3

\section{Investing in Treasury Bills Versus Investing in Wage Growth}

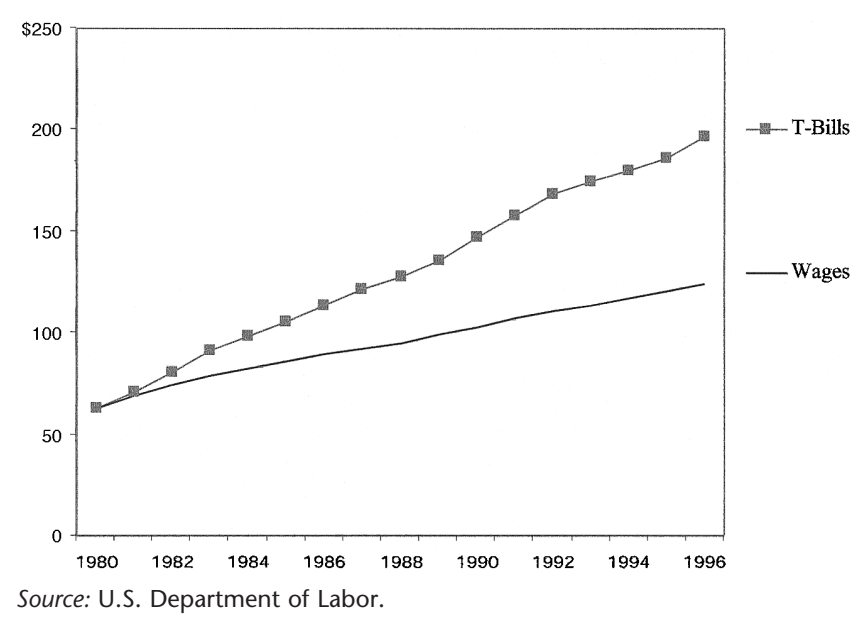


equivalents. Yet, if the data are an indication of the existing macroeconomic patterns, participants may not be reducing their risk by purchasing those money market instruments, but actually improving their returns if they view their DC investments in comparison with participation in DB plans.

Of course, the overall growth rate of wages is not the only determinant of an individual DB pension level. There are other factors, such as individual performance, vesting provisions, and service with an employer. But if these latter factors are not systematic, we should expect a typical predictable pattern of merit and seniority increases to be priced into the bargaining process of wage concessions paid in return for pension benefits. As was stressed previously, if DB plan participation as a security is compared to a DC plan as a security, DC is merely a perfect conduit of underlying asset performance, while DB participation is a derivative security creating wage-dependent cash flows out of the underlying portfolio of capital assets. If this DB derivative security is priced according to modern finance theory, we would expect it to be priced based on the systematic factor of national wage growth.

In his analysis of social security systems (such as the U.S. OASDI, which can be considered a universal DB plan) Samuelson (1958; see also 1975) developed a model in which a steady-state social security system delivers to its participants in the accumulation phase a nominal rate of return given by the compounding of population and labor productivity growth (assuming that labor productivity is fully reflected in taxable payroll and assuming full compliance). The same reasoning naturally applies to DB plans, if taken in aggregate. This is very much in line with financial pricing of DB plan participation. However, in the case of DB plans, only labor productivity is translated into the security performance of DB participation (social security systems have the advantage of compulsory participation with respect to the entire population, thus gaining the possible benefit of demographic growth, tax increases, and increases in population coverage). The data in Table 2 show that labor productivity grew at real rates over 3\% during the period 1948-68, making DB participation a relatively attractive security, while the last three decades have witnessed a dramatic change in the rate of growth of labor productivity, dropping below $1 \%$ real.

As Robert C. Merton says in his discussion of the work of Diamond and Mirrlees (1985), "In a world of full information and perfect markets, where all assets (including human capital) are freely tradable, private pensions provide nothing more than another way for individuals to save. With a full complement of risk-sharing securities available, the worker can fully offset or modify any particular form of payout prescribed by a pension plan" (p. 357). This would suggest that in such a world the workers would hedge their positions in DB plans and create an optimal portfolio of various capital assets, possibly including DB plan participation. Why then did DB plans develop in the first place, and why are we now witnessing such a large shift to DC plans?

Some insights into the economic meaning of DB plans are provided by the analysis of market imperfections embedded in the labor market. The key issue is that human capital is not tradable. Young workers have large amounts of human capital but cannot trade it for any other instruments. This forces such young workers to save more than an optimal amount (as any savings on their part may be excessive, given a large human capital position). Ideally they should seek ways to dissave and, by doing so, pursue diversification of human capital and the resulting reduction of nonsystematic risk (i.e., nonmarket risk of their own human capital). One way to dissave would be to accept lower wages, or lower pension contributions, in return for the purchase of items of value to young workers.

Diamond and Mirrlees (1985) show that optimal labor contracts with nontradable human capital contain a portfolio of options, such as the worker's option to seek other employment. This perspective can be simplified by stating that young workers purchase their mobility by giving up some wages. This can be achieved more efficiently by allocating very small amounts to their pension contributions, instead of directly affecting their wages. One good way to achieve that purpose is through a promise of a DB plan, but with slow vesting.

Bulow and Scholes (1983) provide yet another perspective on the DB plans. They point out that the vesting option can be viewed as being traded between young employees, who purchase it, and 
elderly employees, who hold it and gradually resell it. This results in some compensation of young employees being allocated to vesting option purchase.

Thus, under DB plans, participants can be viewed as holding two types of securities: (1) DB plan participation, whose performance is linked to labor productivity, or wage growth at the macroeconomic level, and (2) various options, including the option to vest, retire early, and so on. In contrast, DC plan participants hold securities that are really the underlying capital assets. It is well known that large amounts of DC assets in the United States are held in low-risk securities, such as money market instruments. Yet in the last two decades even those low-risk securities outperformed the DB plan participation securities, thus giving even very risk-averse DC plan participants higher returns for a comparable level of risk. The main hypothesis here is that the historical shift to DB plans represents a lifetime investment portfolio readjustment on the part of participants. It leaves workers better off in terms of returns, and it appears not to be to their detriment in terms of risk. Indeed, given greater uncertainty of employment (expressed, e.g., in downsizing by many large American corporations), a hypothesis can be ventured that some improvement in their risk profile was achieved. However, the claims of greater uncertainty of employment can be uncertain itself. On one hand, perception of uncertainty, due to downsizing and restructuring, seems to exist among the general public. On the other hand, unemployment had been trending down and is now at historical lows, and empirical studies do not confirm the perception of employment uncertainty.

As is the case with all macroeconomic pronouncements, our explanation of the DC plans' expansion at the expense of DB plans is not easy to prove empirically. Controlled experiments are not possible in the national economy. There are many factors that influence the pension behavior of both employees and employers. One could argue that all pension-related decisions are made solely by employers. This paper disagrees with that perspective, viewing it as too extreme. As pointed out in several analyses in Wise (1985), especially in Wise's own overview, and in Lazear (1985), DB plan participation is strongly associated with union membership and with work in large corporations. Union membership has been in decline in the last two decades, and this to a great degree can be attributed to employees' choices. Also, workers downsized from large corporations do not necessarily pursue employment in other large corporations and may do so by choice. They often opt for self-employment and use DC plans. The 1997 introduction of SIMPLE DC plans for small businesses reflects the growing needs of that portion of the political constituency.

Therefore, it is proposed that, in the face of higher returns of capital assets in DC plans, with the same or lower level of risk as the DB plan participation derivative security, a shift to DC plans is a movement to a superior security, whose superiority is a function of the decline of the importance of wages in the national income. This paper will now attempt to provide an empirical justification for this hypothesis.

\section{Assessing the Hypothesis}

Note that, given the macroeconomic nature of the data, the impossibility of performing controlled experiments, and the fact that we are working with nonstationary time series, the power of statistics is limited when dealing with questions such as this one. Nevertheless, the statistical relationship of returns to labor versus participation in DB plans, if one exists, may shed some new light on the changes in the relative position of DB and DC plans in the recent history of the United States. To examine such a relationship, wages and DB plans must be considered in an aggregated perspective. If individual wages are not growing, but the share of national income to wages is unchanged, then maybe there are too many workers for significant increases in salaries to occur. But such a situation typically would be temporary. I am proposing that a meaningful measure of the significance of wage growth is its growth in relation to national income, that is, the share of national income flowing to wages. Thus I have designed a test of my hypothesis of the causal relationship between the falling relative importance of wages in national income and the falling relative importance of $\mathrm{DB}$ plans in pensions. This is done by comparing several data series.

First, let us compare (1) the portion of all retirement plan assets (or new contributions, benefits, and so on) in DB plans, and (2) the portion 
of total GDP attributable to labor. The first data series can be derived from data published by the Pension and Welfare Benefits Administration of the U.S. Department of Labor (2000), and the second data series can be derived from National Income and Product Accounts as published by the Bureau of Economic Analysis of the U.S. Department of Commerce (2000).

The National Income and Product Accounts express the gross national product of the United States from the income side by providing information about total employee compensation, including waǵes and salaries and nonwage compensation (such as benefits and social insurance contributions), proprietors' income, and income from capital such as rents, dividends, interest, and corporate income. This national accounting procedure allows for an integrated view of income sources for Americans and, from the perspective of this paper, is a valuable source of attribution of income to the factors of labor and capital. The hypothesis will be analyzed by regressing the portion of pension assets allocated to DB plans on the portion of the national income flowing to labor, and, in the second analysis, by analyzing the portion of new pension contributions flowing to DB plans on the portion of the national income flowing to labor. All of the data are annual, as this is the way pension data are provided by the Department of Labor.

This approach may not fully resolve the problem of the relationship of the two variables (DB pension contributions, or assets, and wages). As already pointed out, a macroeconomic approach to pensions brings with it many other questions concerning factors contributing to the changes of the variables analyzed. Furthermore, the time series analyzed are nonstationary and, thus, may require additional analysis, beyond the scope of this paper, concerning their time-dependent behavior. However, I believe that this contribution provides a new perspective that has been largely ignored in actuarial literature.

Figure 4 shows the portion of national income attributed to wages and salaries versus the portion of pension assets in DB plans from 1975 to 1995. It can be argued that wages and salaries do not constitute all of employees' compensation. Because of this concern, the shares of national income to total compensation of employees, are also included as well as the share to total com-
Figure 4

\section{Shares of National Income to Wages, Total Compensation, and Total Compensation Plus Proprietors' Income Versus Share of Pension Assets to DB Plans}

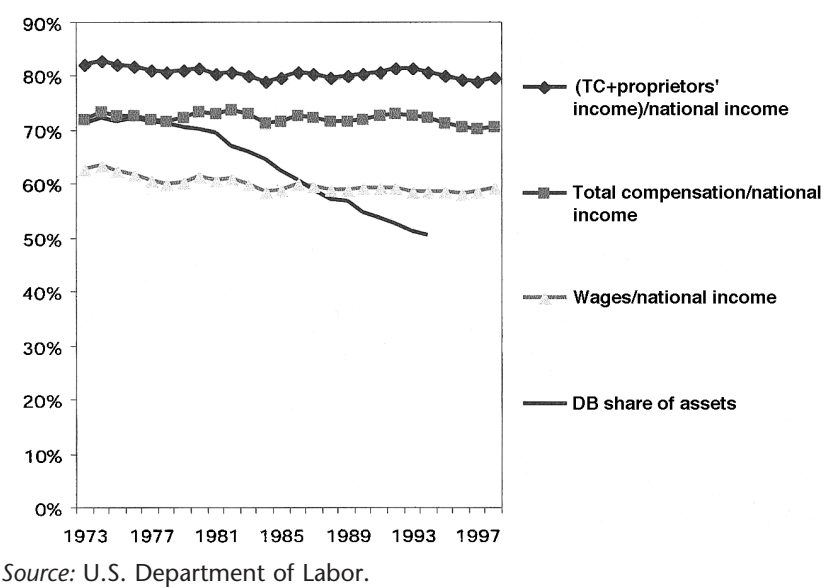

pensation of employees and to sole proprietors (this last quantity representing the widest possible measure of national income attributable to labor). However, from the perspective of this paper it is more appropriate to analyze only wages and salaries as labor's income, as other compensation typically does not affect current pension contributions and employee incentives (especially for DB plans). Note that the most steeply declining curve represents the portion of pension assets in DB plans and that we do not have official Department of Labor data on this data series beyond 1996, while the wages/salaries portion of the national income graph extends through 1998, showing a possibly historic upturn starting in 1997 (not yet compared to the DB portion of pension plans in this analysis).

While the top line in Figure 4, which shows the portion of national income flowing to total compensation and proprietors' income, does not show any significant declining trend, there are some apparent dependencies. For further investigation, only the bottom two lines are repeated in Figure 5: national income share paid in wages and share of pension assets in DB plans. As indicated earlier, wages are the basis for DB benefit level, and they determine long-term returns for DB plan participants.

We can see the striking difference between the attribution of the share of national income flow- 
Figure 5

\section{Share of National Income to Wages Versus Share of Pension Assets to DB Plans}

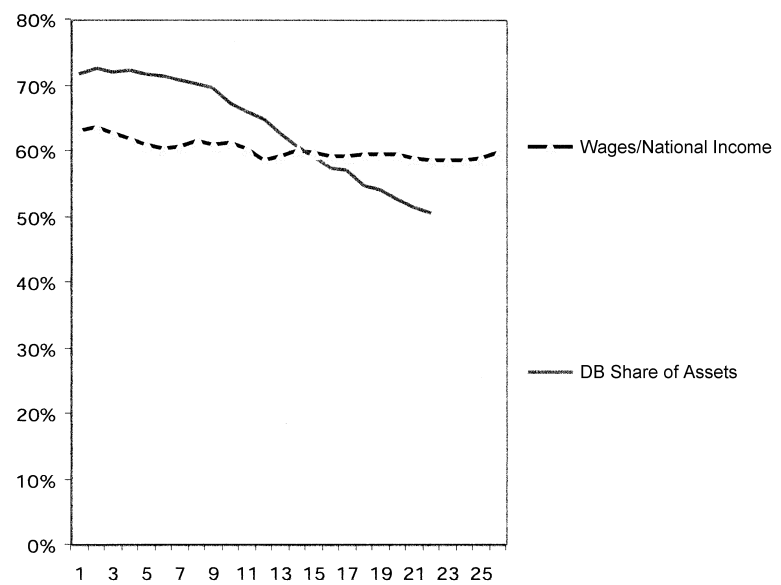

Source: U.S. Department of Labor.

ing to labor by wages and salaries only and the share provided by wages and salaries plus benefits and the share including proprietors' income in Figure 4. While wages and salaries have been mostly in a downward trend established in the 1970 s, the other two measures do not appear to have such a clear trend. As already noted, these two wider measures of labor compensation are typically not included in the wage basis for the calculation of benefits in DB plans. The relative attractiveness of DB plan participation as a security is determined by the growth of what can be termed pensionable earnings, which is represented by wages and salaries.

Figure 5 shows that the share of national income flowing to wages and salaries appears to be correlated with the share of pension assets in DB plans. In Figure 6 we see that there is a very strong relationship between the two variables. The linear model is highly statistically significant ( $p$-value of $0.01 \%$ ), with $R^{2}$ of over $60 \%$ and an adjusted $R^{2}$ of over $64 \%$. Both parameters of linear regression are equally highly statistically significant. The share of national income flowing to wages appears to provide some degree of explanatory power for the share of pension assets in $\mathrm{DB}$ plans.

We may ask, of course, if we should look at new money flowing into DB plans instead of total assets. The response on the part of employees to the economic incentive is probably better repre-
Figure 6

\section{Analysis of Share of Pension Assets in DB Plans Versus Share of National Income Flowing to Wages, 1948-1968}

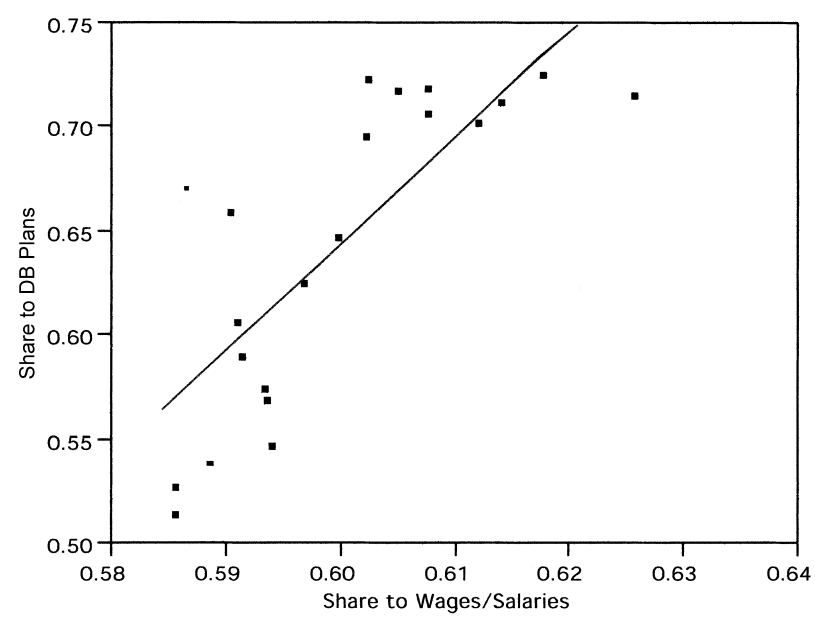

sented by new contributions, but assets are an important part of the picture too, as they represent the wealth of pension plan participants.

Figure 7 shows historical patterns of the share of national income flowing to wages and salaries and new contributions to DB plans as a portion of all pension plan contributions. This is followed by a linear regression in Figure 8. Results indicate an even stronger statistical significance of the relationship, with similar values of $R^{2}$ and adjusted $R^{2}$ as in the case of share of pension assets in DB plans.

Figure 7

Share of National Income to Wages Versus Share of Pension Contributions to DB Plans

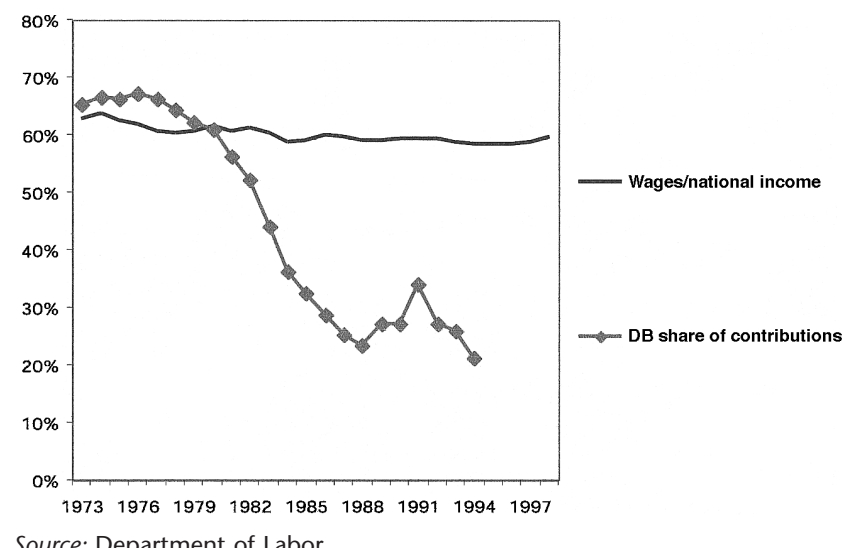


Figure 8

\section{Analysis of Share of National Income to Wages Versus Share of Pension Plan Contributions to DB Plans}

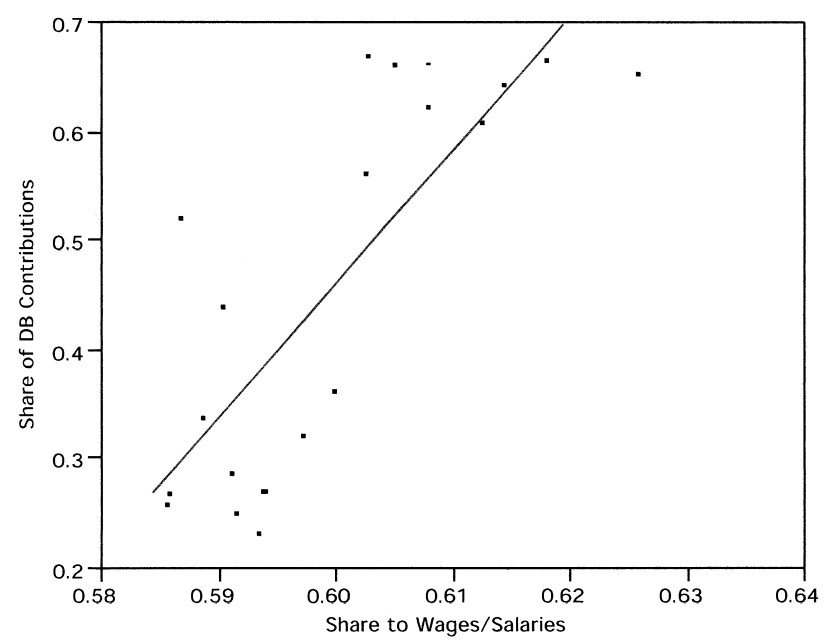

A hypothesis may be ventured that employees are not as quick to respond to economic incentives by changing their pension contributions, their employment contract, or their job as simultaneous analysis of the variables used would imply. This can be addressed by considering the relationship of the share of $\mathrm{DB}$ assets and contributions as a function of the previous year's share of national income flowing to wages, or the year before last, or even further back. An alternative approach would be to study the first difference series. However, such an analysis in the case studied here does not indicate any change in the strength or the nature of the relationships.

To illustrate that, Figure 9 shows the results of an analysis of the share of the national income flowing to labor versus DB assets and DB contributions laggged by one year. Statistical significance does indeed improve, but only slightly. Results for other variables and other time lags, as well as first differences, are similar. Since the processes involved here are long-term macroeconomic phenomena, there may be lags, but they should not affect greatly the underlying economic trends, and in all cases, with or without lags, we can see the statistical significance of the models.

Note also the following:

- The share of DB plan assets in all plans has a 93.41\% correlation to the share of new pension contributions going to DB plans. Even though there was a shift in the relationship between the two plan types, contributions previously going to DB plans were not necessarily redirected to DC plans, but rather newly started plans were apparently mostly of the DC type.

- The share of participant numbers in DB plans also had a very high correlation with the share of total plan assets in DB plans, 90.36\%.

- The share of benefits paid by DB plans had an even higher correlation with the total plan assets share than with the share of participants, at 90.61\%.

The implication of these points is that the shift away from DB plans appears to have been a comprehensive process, and as this analysis points out, it is strongly correlated with the decline of the share of national income flowing to wages and salaries.

Various nonlinear regressions of the same variables as the ones studied above have been performed, but nonlinear regression results turned out to be dramatically less statistically significant, with the exception of odd-power polynomial models, which give close approximations of the linear model.

At this point it seems appropriate to ask one more question: How did the shift out of DB plans correlate with the share of national income flowing to the widely defined compensation of employees? The two time series are shown in Figure 10. Statistical

Figure 9

Analysis of Share of DB Assets in Pension Plan Assets Versus Previous Year's Share of National Income Flowing to Wages, 1975-1995

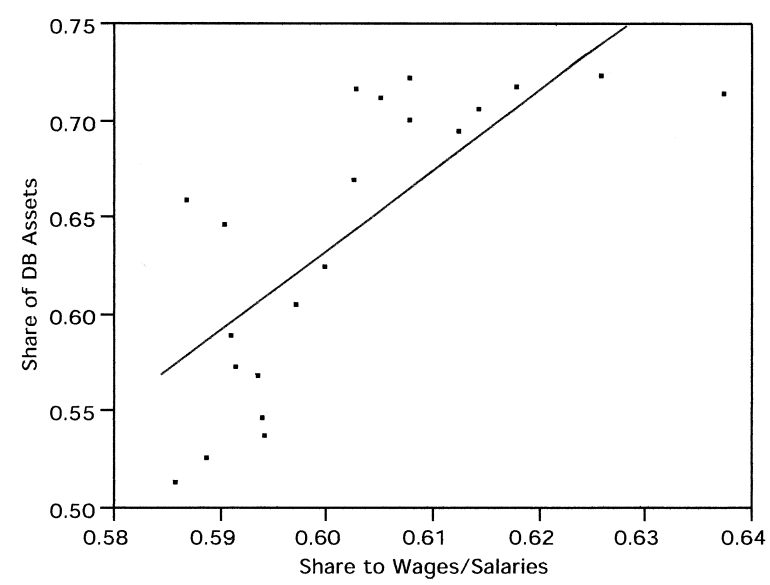


Figure 10

\section{Share of National Income to Total Labor Compensation and Share of Pension Assets in DB Plans}

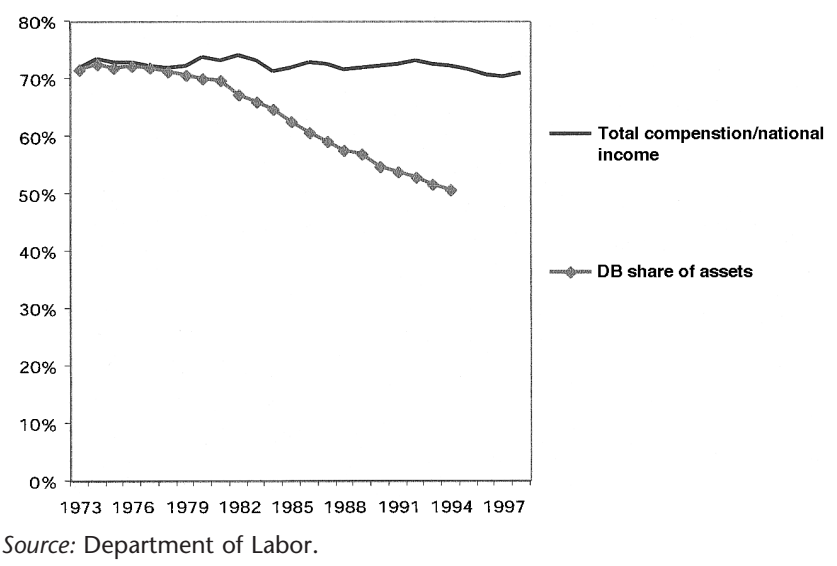

analysis of the DB assets and the share to employees' compensation (not including proprietors' income) appears in Figure 11. We see that the two time series fail to have any meaningful relationship to each other.

It has been a long-standing contention among some economists (Gwartney and Stroup 1995; Surrey 1976) that the share of national income flowing to labor remains more or less constant over time (as it is in the Cobb-Douglas model discussed previously). We have seen from previously presented data that this has not been true of the share going to wages and salaries. However, as shown in Figure 10, the share to total compensation (which includes not only wages/salaries but also the costs of benefits and social insurance contributions paid by employers) has remained relatively stable in the tumultuous years of the last quarter century, with a mean of $72.31 \%$ and the $95 \%$ confidence interval for the mean being $(71.96 \%, 72.66 \%)$.

One must conclude, of course, that the last 25 years have brought about a change in the relationship between total compensation including proprietors' income and wages. Figure 12 shows the trends in the share of national income that belongs to the total compensation of labor but is not paid wages (i.e., cost of benefits and social insurance contributions). This portion of national income has been dramatically increasing, with a rather recent downturn.
Figure 11

\section{Analysis of Share of Pension Assets in DB Plans Versus Share of National Income to Total Compensation of Labor}

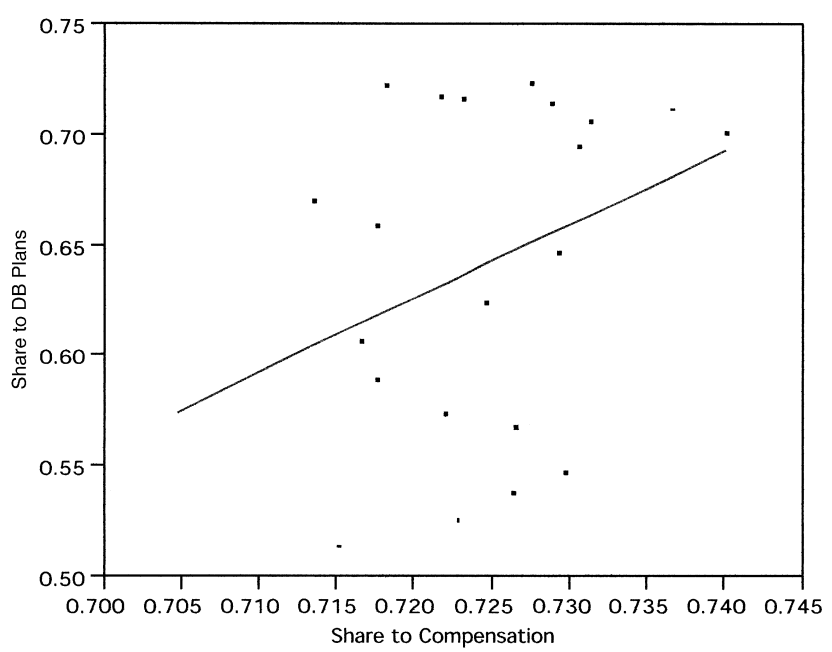

\section{Conclusions}

This paper has shown that a high degree of correlation exists between the shift away from DB plans and the nearly equally pronounced, but not mentioned as often, shift away from compensating labor in the form of wages. As the emerging

Figure 12

Share of National Income Belonging to Total Compensation of Labor but Not Derived from Wages (Benefits and Social Insurance Contributions)

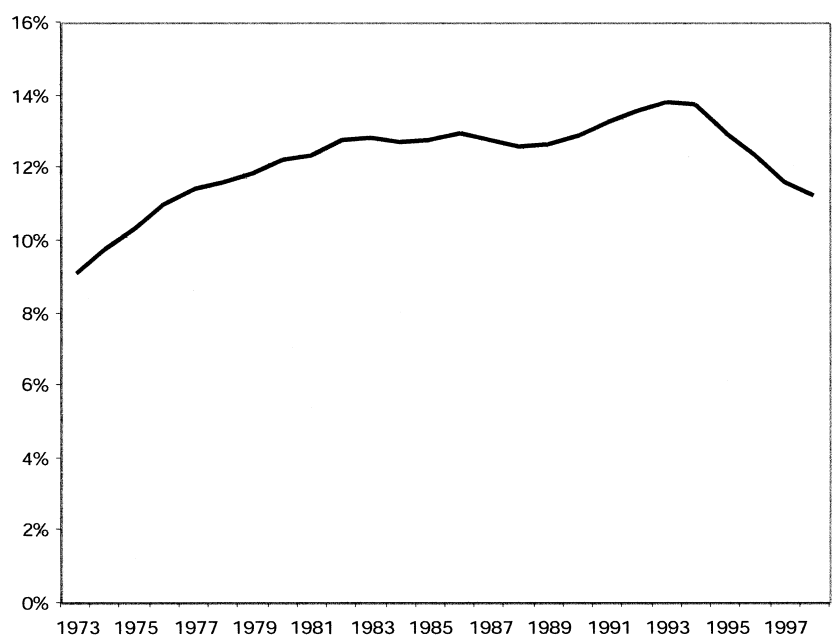


forms of compensation do not lend themselves easily to be the basis for deriving a benefit in a DB plan, it would seem natural that different forms of pensions serve the workers who receive their compensation in a different form. It should be stressed, however, that the best we can do at this point is to derive correlations and hypothesize causations. When two random variables, say, $X$ and $Y$, are correlated, this can generally indicate one of the following three alternatives:

\section{1. $X$ may cause $Y$}

2. $Y$ may cause $X$

3. Both $X$ and $Y$ may be caused by some third variable, or a combination of variables, that may or may not be included in the analysis.

Furthermore, we are not merely studying random variables here; these are time series. As these series are nonstationary, statistical relationships developed here are even more suspect.

Nevertheless, this paper does point to the importance of wages as an index for DB plans and to the weakness of that wage index within national income coinciding with the weakness of DB plans. Actuarial scholars and practitioners may benefit from this observation. We can hope that this correlation may mean causation. It may also mean that both wages and DB plans have been affected by changes in the national economy, the evolving role of government, or changes in risk perception and distribution.

We could even view this analysis as a vindication of the New Economy Theory. The DB plan participation derivative security created by DB plans is indexed to wages and salaries, which have declined in their relative importance in the national income in this new economy and have greatly underperformed securities available in the capital markets. This has created an incentive to purchase other securities, and economic decision makers appear to have responded to that incentive. Also, workers seem to be paid differently in the new economy, not necessarily in direct wages, but in benefits, including ever more expensive health insurance and forms of participation in capital assets such as DC plans, stock options, and, of course, income derived from selfemployment in sole proprietorships. This is, in fact, another way to express the New Economy Theory contention.
Does this mean that the Excessive Regulation Theory is entirely false? To the degree it focuses on some form of bad intentions or conspiracy, it is. However, to the degree that government activities create incentives for economic decision makers, regulators of pension plans who care about the future of DB plans would be well advised to take this analysis into consideration. The implication here seems to be that one possible key to the future of DB plans is to make DB plan participation security indexation to wages and salaries attractive again, or to change the method of calculation of benefit to allow for the inclusion of capital markets' performance. The case for the Risk-Averse Employers Theory is quite weak, given that even risk-free marketable securities (Treasury bills) have provided higher growth of capital than the wage index.

In any case, it must be admitted that there may not be a complete solution to the puzzle of the DB plans' decline here, merely a different perspective on this important issue. DB pension plans have historically given a valuable safety net to American workers. It would be undesirable from the point of view of public policy to allow them to disappear without providing workers with some substitute to meet their needs. DC pensions, as attractive as they appear now, have greater inherent uncertainty about the relationship of the pension and the final salary. Receiving insurance against that uncertainty is a benefit that one day may be desired again by many. This is especially timely in view of the changes in the American economy in the second half of the 1990 s, which seem to indicate a reversal of the historical trend of a decline in the significance of wages in national income. This issue will undoubtedly warrant further investigation.

\section{ACKNOWLedGMENTS}

This work has been prepared as a research paper submitted for credit toward Fellowship in the Society of Actuaries. The author expresses his gratitude to the Research Paper Committee as well as to James Hickman, Ph.D., F.S.A., Shane Chalke, F.S.A., and the anonymous referees for their advice in the preparation of the work. All statistical analysis of this work was performed using JMP, a statistical software package for the Macintosh operating system. 


\section{References}

Bharmal, Shiraz Y. M. 1988. "Debate No. 7: Defined Benefit Pension Plans Are Not Well Suited to Tomorrow's Work Force and Should Be Replaced by Defined Contribution Plans." Proceedings of the Canadian Institute of Actuaries 19(2):117-33. Proceedings from the March 7-8, 1988, Special Meeting of the Canadian Institute of Actuaries.

Bodie, Zvi, Alex Kane, and Alan J. Marcus. 1999. Investments. 4th ed. New York: Irwin McGraw-Hill.

Bulow, Jeremy I., And Mrron S. Scholes. 1983. "Who Owns the Assets in a Defined-Benefit Pension Plan?" in Financial Aspects of the United States Pension System, ed. Zvi Bodie and John B. Shoven, pp. 17-36. Chicago: University of Chicago Press.

Cooper, James C., and Karl Borden. 1997. "The Interpretation of Wages and Prices in Public Historical Displays." Public Historian 19(2): 9-36.

Diamond, Peter A., and James A. Mirrlees. 1985. "Insurance Aspects of Pensions." Comment by Robert C. Merton. In Pension, Labor, and Individual Choice, ed. David A. Wise, pp. 317-56. Chicago: University of Chicago Press.

Gwartney, James D., and Richard L. Stroup. 1995. Economics: Private and Public Choice. 7th ed. Orlando, FL: Harcourt Brace \& Co.

Lazear, Edward P. 1985. "Incentive Effects of Pensions." In Pension, Labor, and Individual Choice, ed. David A. Wise, pp. 253-82. Chicago: University of Chicago Press.

Marcus, Alan J. 1987. "Corporate Pension Policy and the Value of PBGC Insurance.” In Issues in Pension Economics, ed. Zvi Bodie, John B. Shoven, and David A. Wise, pp. 49-81. Chicago: University of Chicago Press.

Merton, Robert G. 1983. "On the Role of Social Security as a Means for Efficient Risk Sharing in an Economy Where
Human Capital Is Not Tradable." In Financial Aspects of the United States Pension System, ed. Zvi Bodie and John B. Shoven, pp. 325-58. Chicago: University of Chicago Press.

Poterba, James M., Sean Venti, And David A. Wise. 1994. "401(k) Plans and Tax-Deferred Saving." In Studies in the Econom$i$ cs of Aging, ed. David A. Wise, pp. 105-42. Chicago: University of Chicago Press.

Samuelson, Paul A. 1958. "An Exact Consumption-Loan Model of Interest with or without the Social Contrivance of Money." Journal of Political Economy 46 (December): 467-82.

- 1975. "Optimum Social Security in a Life-Cycle Growth Model." International Economic Review 16 (October): 531-38. Reprinted in Collected Scientific Papers of Paul A. Samuelson, vol. 4. Cambridge, MA: MIT Press.

Surrey, M. J. G., ED. 1976. Macroeconomic Themes. Oxford: Oxford University Press.

U.S. Department of Commerce, Bureau of Economic Analysis. 2000. National Accounts Data. Available online at http://www. bea.doc.gov/bea/dn1.htm.

U.S. Department of Labor, Pension and Welfare Benefits AdminisTRATIOn. 2000. Private Pension Plans Bulletin, Abstracts of 1996 Form 5500 Annual Reports. Available online at http://www.dol.gov/dol/pwba/public/programs/opr/bullet1996/ cover.htm.

Wise, DAvid A., ED. 1985. Pension, Labor, and Individual Choice. Chicago: University of Chicago Press.

Discussions on this paper can be submitted until Jan. 1, 2002. The author reserves the right to reply to any discussion. Please see the Submission Guidelines for Authors on the inside back cover for instructions on the submission of discussions. 